\title{
Sustainable Land Use Planning Solutions for Water Supply Reservoirs in Serbia
}

\author{
Jelena Živanović Miljković ${ }^{1}$, Marijana Pantić ${ }^{1}$ and Ljubiša Bezbradica ${ }^{1}$
}

\begin{abstract}
This paper starts from the fact that spatial and urban planning promote rational land use planning and express interests in the sustainable development of land, water and related resources and infrastructure. The authors here look for sustainable land use planning solutions in the domain of water management within the spatial plans. A starting point of this paper is the fact that integration of water management issues (i.e. drinking water management) into land use planning is essential in achieving sustainable development. Considering this, the paper focuses on analysis of land use planning solutions given within three spatial plans that include areas of water supply reservoirs. The authors give an analysis of the set of measures prescribed by zoning ordinances within spatial plans concerning water protection and protection from water (i.e. flood water evacuation). The authors conclude that analyzed spatial planning documents give sustainable land use solutions, since land use planning, through the zoning, represent a starting point in water protection.
\end{abstract}

Keywords: Spatial Planning, Sustainable Land Use, Water Management, Water Reservoirs, Serbia

\section{Introduction}

Sustainable water resources management and securing availability of water resources are among 17 global sustainable development goals that should be achieved until 2030 at all levels (UN, 2015). The Water Framework Directive (2001), regulates an integrated water protection in the EU and it requires the spatial identification of all activities liable to have impact on water bodies.

Water management issues have a spatial planning dimension (Dühr et al., 2010), where the spatial planning plays a significant role in water protection. Largely successful, the integrated water resources planning approach has become a guiding principle for countries worldwide. Rodríguez et al. (2015) emphasize that it is necessary to establish coordination strategies between land use planning and water resource management, which is expected to improve future sustainability of a region. Nevertheless, it was noticed that there is certain disconnection between land use planning and water resources planning due to different levels of government and decision makers responsible for land use planning and for water planning (Tarlock, 2002; Dobricic, Marjanovic, 2017).

There are water reservoirs of different primary purpose - for water-supply, energy production (hydro power-plants) or for mitigation of consequences expected due to torrent flows. In the case of reservoirs planned for water-supply, use of the surrounding land is more restrictive. This is in other to secure their primary purpose - high water quality. On the other hand, legal and planning framework allow much higher level of creativity when it comes to multifunctional land use and development of activities around reservoirs with primary function in energy production or mitigation of excessive precipitation impact (Pihler et al., 2013; Danilović Hristić et al., 2018).

In cooperation with other complementary disciplines, spatial planning in Serbia 
represents the key instrument for balancing between land use change and consequences that the change can bring (Spasić et al., 2009). The practice of changing environment exists in the country since centuries, which includes construction of complex elements of infrastructure such as - river regulations, embankments, dams, irrigation and drainage systems, etc. (Dobricic, Marjanovic, 2017). Without spatial planning and spatial plans, water management in Serbia would remain mainly in jurisdiction of public institutions that take care only on sectoral and technical issues, thus omitting integrated approach and complexity of environment (Pihler et al., 2013). Therefore, the role of spatial planning is to balance between protection and development, which is reflected in relativization of conflicts (Pantic et al., 2018).

This paper starts from the fact that planning, regulation and use of space in Serbia bases, inter alia, on the principle of rational and sustainable use of resources. The authors systemize and evaluate land use solutions given within the planning documents developed for special purpose areas for the water supply reservoirs, following their main purposes - water supply and protection against flooding.

\section{Methodology}

The research is conducted using qualitative research methods, literature review, document analysis, analysis of the institutional and regulatory framework and case study analysis. The international documents set out the context of the analysis, but the main focus was on analyzing the national spatial documents. The documents have been analyzed in order to identify sustainable land use planning solutions for water resources management in Serbia. In order to present the water resource issues within the planning, the authors conducted an analysis of the case studies represented in newly developed special purpose area spatial plans (SPASPs) for existing water supply reservoirs Prvonek and Vrutci, and for planned water supply reservoir - Jelašnica (Figure 1), adopted in the period 2017-2018. Comprehensive qualitative assessment of the land use planning solutions regarding measures for water protection and protection from water is defined regarding restrictions implemented in land use (Prvonek and Vrutci) and land use change in case of the planned water reservoir (Jelašnica) (Table 1).

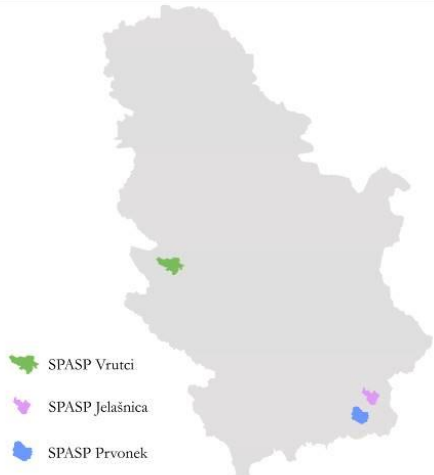

Figure 1: The location of case studies in the Republic of Serbia.

Source: elaborated by the authors. *The map is symbolic. 
Table 1: Basic spatial and land information of analysed SPASPs.

\begin{tabular}{|l|c|c|c|}
\hline Reservoir & $\begin{array}{c}\text { Watershed within } \\
\text { the plan (\%) }\end{array}$ & $\begin{array}{c}\text { Area outside of } \\
\text { watershed (\%) }\end{array}$ & $\begin{array}{c}\text { Average terrain slope in } \\
\text { watershed (\%) }\end{array}$ \\
\hline Jelašnica & 35.4 & 64.6 & 30.0 \\
\hline Prvonek & 75.0 & 25.0 & 35.0 \\
\hline Vrutci & 54.4 & 45.6 & 18.3 \\
\hline
\end{tabular}

Source: SPASP Jelašnica, 2017; SPASP Prvonek, 2018; SPASP V rutci, 2018.

\section{National Legal Framework for Sustainable Land Use and Water Management in Serbia}

The Republic of Serbia, in accordance with its European integration process, continuously performs activities on innovation of the strategic, legislative and planning framework. Serbia has the main strategic documents governing the environmental policy, including water resources, together with implementation programs. The national development policy framed by various strategies, aims to define the basic conditions for the implementation of the globally accepted trend of sustainable development.

Sustainable use and protection of natural values in Serbia is provided by solutions of Spatial Plan of the Republic of Serbia (2010) and National Strategy for Sustainable Use of Natural Resources and Properties (2012), while long-term water management directions are determined by the Water Management Strategy (2017).

Water is a natural resource and it is owned by the Republic of Serbia. Both water and water land are considered as public good. Unlike water, water land can be in all forms of ownership (private, public and cooperative). The state is concerned about integrated water management i.e. to implementation of measures and activities aimed at maintaining and improving the water regime, ensuring the required quantities of water required for different purposes, protection of water against pollution and protection of other assets in the case of extreme water events.

Water Management Master Plan of the Republic of Serbia (2002) is a long-term plan for the maintenance and development of the water regime in an entire or part of a water area in Serbia. It establishes a basic strategy for water use, water protection and protection from water, and provides solutions that ensure the maintenance and development of the water regime, with the most favorable and best-performing technical and financial solutions for integrated water management. This document is in the accordance with the Spatial Plan of the Republic of Serbia, the strategy in the field of environment and other relevant domestic planning documents. Nevertheless, the role of this document within the current planning and regulatory framework remains unclear despite the fact that this document contains valuable strategic directions not all of which have been integrated into the Water Management Strategy (Dobricic, Marjanovic, 2017).

Water protection issues have a legal basis in the Law on Environment Protection (2004) and the Law on Water (2010). The Law on Environment Protection (2004) regulates integrated environmental protection system and establishes natural values management through the planning of sustainable use and the preservation of their quality and diversity. The Law on Water (2010) regulates the legal status of waters, integrated water management (use and protection of water, protection against water and development of 
water resources), management of water facilities and water land ${ }^{1}$. Water land is in function of maintenance and improvement of the water regime and it is used for the construction and reconstruction of water facilities, maintenance of the river beds, as well as for protection against harmful effects of water. Also, water land can be used for construction of other public facilities (i.e. public line infrastructure facilities) or for the performing of economic activities (i.e. formation of temporary gravel and sand deposits; sport, recreation and tourism; agricultural activities).

In addition, both laws on water resource protection proclaim the establishment of three levels of protection - i.e. zones of protection, which are further regulated through bylaws. This primarily involves delineation of a construction zone at multiply locations, which depends on the capacity of the water resources and on the level of vulnerability, as well as the purpose of the construction on the locations. In certain zones, where the protection area is delimited, some activities are being allowed by regulations that are in accordance with the primary purpose for which the reservoir was created.

\section{Relationship between Land Use Planning Solutions and Water Resources}

Spatial planning is an activity primarily aimed at protecting goods of public interest. As such, it is also recognized as an area that is a segment in water protection (Water Management Strategy, 2017), since water supply represent an activity of public interest. In Serbia, the Law on Planning and Construction (2009) (LPC) regulates the field of spatial and urban planning and the adoption of planning documents, the documents for the implementation of spatial plans, as well as the urban technical documents. Spatial planning documents include the Spatial Plan of the Republic of Serbia, regional spatial plans, spatial plans for the local governmental units and special purpose area spatial plans. After adoption, implementation of a spatial and an urban plan is legally binding for all institutions at national, regional and local level.

The spatial planning documents contain protection measures, regulation and use of all elements of the environment, as well as water resources. National spatial plan, i.e. the Spatial Plan of the Republic of Serbia (2010) could also be concerned as a legal act, since it is adopted and published in the same manner as any other law. It defines proposals and directives for all spatial development issues and measures and instruments for their implementing.

One of the basic actions by which spatial planning protects water resources, as well as public interest, is land use zoning. The zoning, as established standards of acceptable land use, helps to control undesirable impacts and represents the best way to reduce spatial conflicts in land use (Pantić et al., 2019). The Order on Protection Regimes (2012) defines three levels of protection within zone of protection whereby I level of protection regime strictly prohibits any use of natural resources, the construction, works and activities within the protected area. Since water sources are being assigned three zones distinguished by level of protection (by the Law on Nature Protection), spatial planning integrates them into land use planning process.

1 Water land is the land constantly or occasionally under the water, for which special hydrological, geomorphological and biological relations occur and impact the water and coastal ecosystems. 
According to the Law on Environment Protection (2004) the development of a strategic environmental impact assessment is mandatory for all strategies, plans, programs and represents the bases for spatial and urban plans, i.e. for land use planning. The procedure for developing spatial and urban plans, as well as the Strategic Environmental Impact Assessment, implies public participation in decision making.

Therefore, the task for spatial planning is to, within defined protection zones that allow few or more diverse types of construction, subtract locations where these activities are still prohibited - this refers to locations of public interest such as water-source zones (Pantic et al., 2019). Consequently, planning solutions and propositions define the "regime of use", i.e. obligations and restrictions regarding the manner of use (Živanović Miljković, 2018), while such zoning within spatial plans often put limitations or prohibition of building in order to preserve public interest and sustainable use of natural resources. Owners of immovable property i.e. land and buildings / facilities are restricted in the use of their property by certain obligations and responsibilities.

The legal framework in Serbia is very decisive regarding the prohibition, limitation of rights and obligations of owners and users of water land and water facilities. Namely, an owner, i.e. an user of the property (land, i.e. parcel and facilities) located in the zone of sanitary protection, is obliged to adapt the way of using its own property to the newly established conditions for the use and maintenance of the sanitary protection zone. The water source sanitary protection zone is also implemented in the land use planning process, since the Law on Planning and Construction sets the principles and protection, regulation and development propositions. Also, the boundaries of water land are usually included into spatial and urban plans.

\section{Results and Discussion}

Spatial planning regulates sustainable land use within water management by defining principles, goals, general and specific aims, as well as by defining measures according to certain topic (e.g. agriculture, forestry, environment). The primary role of the SPASPs, analysed for the purpose of this paper, is water supply, with tendency to define use of the areas in multifunctional purposes. Additional activities, which are also subject of SPSPs, are the most commonly water protection, protection against water, silt control, tourism, and in some cases energy production. Spatial plan, as a document, has a fundamental role for sanitary protection of an entire watershed and facilities build for water protection and protection against water purposes. Whenever it is possible (depending on the state government decision), SPASPs cover the broader area than the watershed itself in order to use more flexible land use possibilities for economic revival outside of the sanitary protection zones. This aspect is particularly relevant for local communities and for enhancing general territorial balance at the national level, because areas planned for construction of water supply reservoirs are usually mountainous, sparsely populated and economically hindered. In addition, spatial plans are also foundation for solving property rights issues, setting building parcels for hydro-technical facilities and separation of water land from other types of land use. As such, spatial plans contain information about current state on soil types, terrain geology and erosion risks. Even though some protection measures are defined already by the acts at the national 
level and through activities of responsible institutions (e.g. in forest management), spatial plans integrate different sorts of protection measures, taking care to balance the primary purpose to protect a water reservoir and, on the other hand, to bring in certain elements with potential to animate the area. One of the examples where protection measures are being defined before development of a plan is forest categorisation according to international ecological certificate - SGS-FM/COC-009244, which defines High Conservation Value Forests (HCVF), i.e. forest land of high importance. The forests are usually designed as anti-erosion and water purification measure. Another example is sanitary protection zoning that is, prior to a spatial plan, defined by the Order on Methods for Delimitation and Maintenance of Sanitary Protection Zones at Watersupply Source (Official Gazette, 2008). Since the Order regulates restrictions, a SPASP task is to upgrade it by defining activities which are allowed and complementary to the primary purpose of reservoir area.

Table 2: Land use planning solutions for water resource management in Serbia.

\begin{tabular}{|c|l|}
\hline & - Defining (protection) zones \\
& - Introduction of solid waste and waste water collection and treatment system \\
& Regulation (sanitation) of existing dumps \\
& Introduction of water collection and water treatment system \\
- Establishment (improvement) of monitoring system
\end{tabular}

Source: based on SPASP Jelašnica, 2017; SPASP Prvonek, 2018; SPASP V rutci, 2018.

\subsection{Zoning}

Zoning of a spatial plan area is the base for defining other measures. Usual procedure in spatial planning of a special purpose area for water-supply sources is territorial division in four zones: zone of I, II, and III level of protection and fourth zone which is not explicitly in function of protection.

Zone of I level of protection is actually the zone of implicit sanitary protection, delimited in such a way to include reservoir itself with reservoir's surface and a $10 \mathrm{~m}$ wide belt in horizontal projection from the reservoir's surface at the maximal level outwards. In addition, the zone includes all streams in the watershed, but with the difference that the 10 -year water peak level is taken as a reference. Almost all activities are restricted in the 
zone, except those with purpose of the system control, monitoring and maintenance. Therefore, it is not allowed to use motor boats, to swim (people or animals), practice agriculture, build or dispose waste. What is allowed, but is not directly related to watersupply source functioning, is fishing for non-commercial purposes. Short sections of road infrastructure are also allowed, because it is necessary for system maintenance.

The zone of II level of protection is defined as inner zone of sanitary protection. It starts at dam and spans upstream in $500 \mathrm{~m}$ width horizontal projection from the edged of the I zone outwards. Activities that are restricted in this zone are building residential buildings, accommodation and sport facilities, gathering in large number (e.g. for a manifestation, camping). Agricultural activities are allowed, but with no use of pesticides or herbicides. Existing rural households are obliged to secure safe and sanitary waste water collection and treatment within twelve months from the day of the SPASP adoption. The buildings or facilities are allowed to be refurbished and adapted to other suitable purposes. Any kind of mining activities is forbidden as well as waste dumps, extension of cemeteries or formation of new ones. Exploitation of woods is allowed, but not the clear-cutting.

The zone of III level of protection, defined as zone of broader sanitary protection, occupies remaining territory of water-supply source watershed (watershed without the zones of I and II level of protection). The activities that are also restricted in this zone are mining, waste disposal and free waste-water disposal. Therefore, residential and tourism buildings and facilities, which are allowed here, are matter of controlled development. In common cases, when settlements consist of hamlets or houses scattered over hilly/mountainous terrain, defined solution for waste-water and sewage is a system built at a household level, alternatively at the level of a household group. However, the local systems are defined to be impermeable, so that surface and ground water quality within watershed is not to be impaired. From the aspect of tourism development, this zone is open for picnic activities, hiking and biking trails, construction of view-points, shelters and restaurants.

The zone IV is not defined by legislative acts, but it is included in the SPASPs. It extends from the outer line of the zone III to inner line of area defined as subject of spatial plan. This zone is reserved to more flexible activity and economic development, including communal and accommodation infrastructure, and commercial activities in function of economic revival of rural areas. The rules of protection, valid for the zone, are not defined by SPASPs or legislative acts, but by local planning documents (urban and spatial plans).

\subsection{Waste problems}

For low population density, rural areas have become just recently treated more seriously regarding solid waste and waste-water collection and waste-water disposal in Serbia. Since water treatment has not been set as a standard in all urban areas, current focus of spatial plans is rather on solid waste treatment. The waste issue is highly relevant in the case of water-supply sources because purpose of an entire system can be endangered by water or solid waste pollution. Due to the organized waste collection and disposal, there are vast of illegal dumps and landfills spread out through rural areas. The most common locations are river beds, ravines, areas along the roads.

In analysed plans, starting point is areas without organized collection and disposal 
system. In order to solve the problem, SPASPs, at the first place, suggest removal of existing illegal waste dumps and sanitation of the locations, followed by waste evacuation outside of the watershed area, particularly outside of the zone of I and II level of protection. The plans also define locations for regional landfills that are target points for solid waste disposal, both for the waste collected by sanitation of illegal dumps and for the future waste collection activities. The measure also includes disposal of waste produced by domestic animals. The plans also suggest a decentralized waste management system in rural settlements in a form of mobile centres. Expectedly, those documents proclaim prohibition of the disposal in places that are not defined as waste dumps, including the disposal of municipal and construction waste into the watershed.

Ironically, households within water-supply source and its watershed do not have organized water-supply, but rather solved issue at individual or household level. In a system where water-supply is not collectively resolved, it is not to expect that wastewater treatment issue is solved. Therefore, SPASPs try to tackle the issue by defining introduction of controlled and sanitarily safe collection and treatment of waste-water (communal and atmospheric water, and water used in agriculture).

\subsection{Monitoring}

Some forms of monitoring usually exist within the territories of analysed plans, but it is conducted irregularly or incompletely regarding parameters range. Therefore, it cannot be said that spatial plans proclaim establishment of monitoring system, but it could be certainly stressed that plans are relevant in raising awareness on this topic by demanding improvements. It proclaims systemic monitoring of both quantitative and qualitative features of water in a reservoir, of the streams pertaining to the watershed and of the water-sources of the individual households.

But not only water is to be monitored. The plans also proclaim monitoring over soil qualities. Another measure regarding monitoring in water-supply source areas is creation of a polluter cadastre (a data-base including spatial allocation of data). Even though it is not explicitly stated in the plans, the cadastre could be combined with an intensified inspection and prevention of illegal building, which is significant problem, not only in analysed areas but in the entire country. Lastly, the proclamation for an introduction of information and monitoring system on forests it should be mentioned.

\subsection{Anti-erosion measures}

In the remote areas around the existing Prvonek water reservoir and the planned Jelašnica reservoir, erosion is a result of natural processes. However, in the case of the Vrutci reservoir and its watershed, anthropogenic action consequences are more significant because the area is located closer to the more densely populated settlements. However, the anti-erosion measures defined by the spatial plans are distinguished as biological measures and technical measures.

In the group of biological measures pertain the afforestation and melioration of pastures, grassing the grooves, an erection of wattle and other barriers to prevent soil wash-out. For the already forested areas, the monitoring it planned and for some of the areas endangered by erosion an introduction of new forests is planned. On the other hand, planned technical measures are conduction of action for reservoir protection from 
eutrophication. All in all, forests are seen as the protectors of water in the entire watershed. Building various elements of supra- and -infrastructure, the plans aim at protection from blizzards in winter, natural disasters in summer (storms, torrents, and landslides), etc.

\subsection{Flood water evacuation}

Besides its primary function to secure quality water supply to the entire region, the reservoirs have a protective function. As artificial structures, the reservoirs have capacity to control level of water, which can be adjusted according to current needs. In the case of torrent flows appearing in small streams within watershed, a raising level of the reservoir surface can be allowed. This action is combined with a bell-mouth spillway, which ends with a slowing slope in order to mitigate water energy of the incoming wave. This is the case of embankment dams (Prvonek and Jelašnica).

The other case is a system at gravity dam (Vrutci), which is made of concrete. A water flow system in regular situations here consists of outlets in the lower half of the construction, but in the case of water peak or flood is designed a system of overflow windows. The system consists of the openings (windows), placed one next to each other, in the central part of the dam. With its height of $3 \mathrm{~m}$ and length that takes approximately $20 \%$ of overall length of the dam, they are positioned high on the construction, close to the crown of the dam (Figure 1). The system is designed for flood waves and it could successfully manage a 10.000 years water peak, thus preventing flooding downstream from the dam.

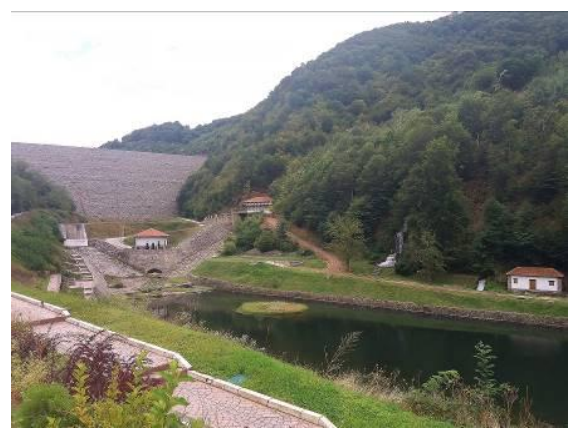

(a) Prvonek dam

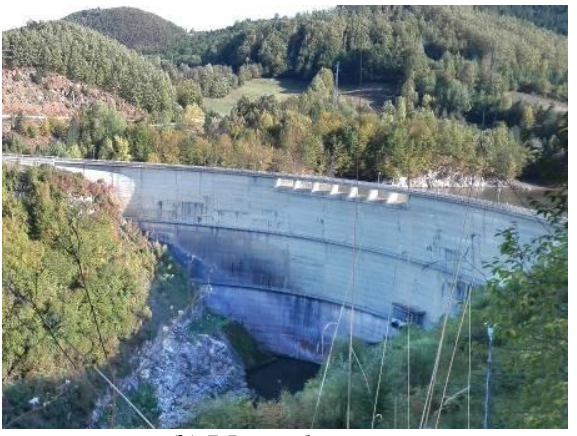

(b) Vrutci dam

Figure 2: Types of dams and peak water protection systems. Source: LAUS, 2017.

\subsection{Cemeteries under the control}

In spite of the fact that water-supply reservoirs are placed rather in remote areas, they are inhabited by a century long inheritance of settlements, which keep part of the history at local cemeteries. Land use solutions within SPASPs allow the extension of existing cemeteries only in the zone of III level of the protection and only in compliance to protection measures defined for this zone and in accordance to the sanitary standards.

\subsection{Raising awareness of population}

One part of the listed measures greatly depend on the public institutions, their 
financing, prompt organisation and maintenance willingness. However, the role of the local population is also of atmost relevance because they are the direct users of the space and could harm the system if they do not understand well its purpose and significance. Therefore, rising a level of informativeness (informal ways) and education (formal way) are additional measures prescribed by spatial plans in order to maximise positive outcomes. Informativeness and education is not relevant to spread only among the local population, but also among the visitors (tourists, mountain-hikers, bikers, etc.).

In effort to ensure the best results, the SPASPs introduce certain measures for balancing between restrictions and incentives. For example, key measure for the ecosystem capacity preservation is an introduction of the payments for water-related ecosystem services and complementary institutional and organisational adaptations. On the other hand, imposed restrictions are mitigated by some forms of compensation to the local population.

\section{Conclusions}

The water management issues are present in land use planning process, since the water protection is an obligatory issue that has to be considered within all planning documents. The spatial planning documents have a significant integrative role and represent a guiding development instrument of development of the analyzed areas. The land use planning, as one of the mechanisms with an impact on the reduction of pressure on land and other resources (Živanović Miljković, Popović 2014), as well as zoning regulations and implementation of plans are typically enacted to address measures for resource protection.

The SPASPs are being currently in implementation. The analysis of land use planning solutions has shown that the SPASPs introduced both measures for water protection and protection against water. At the same time, these measures also have a legal basis for the implementation, with clear delegated tasks in operationalization.

The measures set by the special purpose area spatial plans in order to regulate land use within watershed of the water-supply reservoirs are partially imposed by legislative acts, but, on the other hand, they are shaped out through the spatial planning solutions. The protection zones, and zoning in general, are the starting point in land use planning, where creativity in shaping land use is limited, but, therefore, spatial plans, whenever it is possible, delineate spatial plan territories broader than watersheds themself. This allows to the spatial planners to be more creative in featuring not only protection measures but also development measures.

The primary goal of spatial plans prepared for the type of analysed areas - water-supply sources - is securing high quality of water in reservoirs (I or I/II class by national standards), as well as in all streams within the watershed. This indicates that the primary task of spatial plans is in compliance with primary purpose of the reservoirs. Considering the complexity of the water-system in nature, measures proposed to regulated watersupply are not related only to water protection, but also to soil and biodiversity protection, as well as innovativeness and education of local population and other beneficiaries of the areas.

An adequate land use and regulation also implies the implementation of planning solutions, and cooperative planning between water management and land use. It is 
necessary to respect the zoning and land use solutions at all levels.

\section{Acknowledgements}

This chapter has been prepared within the scientific projects No. III 47014 and TR 36036, financed by the Republic of Serbia Ministry of Education, Science and Technological Development in the period 2011-2019.

\section{References}

Danilović Hristić, N., Stefanović, N., Petrić, J. (2018). Opportunities for Development of Tourist Potentials in Protected Areas of the Water Storage Reservoirs, on the Example of Spatial Plans of the Special Purpose Areas in Serbia. In Facta Universitatis Series: Architecture and Civil Engineering Vol. 16, No 3 (pp. 489-500).

Dobricic, M., Marjanovic, P. (2017). Interaction between Water Protection and Spatial Planning. Water Research and Management, Vol. 7, No. 3, pp. 3-15.

Dühr, S., Colomb, C., Nadin V. (2010). European Spatial Planning and Territorial Cooperation, Routledge: London.

IAUS (Institute of Architecture and Urban \& Spatial Planning of Serbia) (2017). Internal database. Belgrade.

Law on Environment Protection, Official Gazette of the RS, No. 135/2004, 36/2009, 36/2009, 72/2009, 43/2011, 14/2016, 76/2018, 95/2018, 95/2018).

Law on Nature Protection (2009/2016), Official Gazette of the Republic of Serbia No. 36/2009, last amended in 14/2016.

Law on Planning and Construction, Official Gazette of the Republic of Serbia No. 72/2009, 81/2009 - corr., 64/2010 - Constitutional Court decision, 24/2011, 121/2012, 42/2013 - Constitutional Court decision, 50/2013 - Constitutional Court decision, 98/2013 - Constitutional Court decision, $132 / 2014,145 / 2014$.

Law on Water, Official Gazette of the Republic of Serbia, No. 30/2010, 93/2012, 101/2016, 95/2018 and 95/2018 - other Law.

National Strategy for sustainable use of natural resources and properties, Official Gazette of RS, No $33 / 2012$.

Order on Methods for Delimitation and Maintenance of Sanitary Protection Zones at Water-supply Source (2008). "Official Gazette of the Republic of Serbia" No. 92/2008.

Pantic, M., Milijic, S., Zivanovic Miljkovic, J. (2018). Spatial Planning as a Land-Use and Building Regulation Tool for Protected Natural Areas in Serbia. In P. Mitković (Ed.), ICUP2018 2nd International Conference on Urban Planning - Proceedings (pp. 331-338). Niš (Serbia): Faculty of Civil Engineering and Architecture, University of Nis.

Pantić, M., Živanović Miljković, J., Milijić, S. (2019) Land Use and Building Regulations: The Case of Spatial Plans for Protected Natural Areas (Serbia), Facta Universitatis Series: Architecture and Civil Engineering, (in press).

Pihler, V., Zelenović Vasiljević, T., Dunčić, D. (2013). Water Management, Environmental Protection and Spatial Planning Reconciliation - "Accommodating" the Danube and the Tisa River in Serbia. Spatium 29. 49-52.

Rodríguez, M. I., Grindlay, A. L., Cuevas, M. M., Zamorano, M. (2015) Integrating land use planning and water resource management: threshold scenarios - a tool to reach sustainability, WIT Transactions on Ecology and The Environment, Vol 192, Ecosystems and Sustainable Development X, WIT Press, pp. 231-242.

Spasić, N., Jokić, V., Maričić, T. (2009). Managing Spatial Development in Zones Undergoing Major Structural Changes. Spatium 21. 53-65.

Spatial Plan of the Republic of Serbia, Official Gazette of the RS, No. 88/10.

Special Purpose Area Spatial Plan for Jelašnica Water Supply Reservoir (2017). "Official Gazette of the Republic of Serbia” No. 39/2017. 
Special Purpose Area Spatial Plan for Prvonek Reservoir (2018). "Official Gazette of the Republic of Serbia" No. 89/2018.

Special Purpose Area Spatial Plan for Vrutci Reservoir (2018). "Official Gazette of the Republic of Serbia" No. 89/2018.

Tarlock, A. D. (2002). Connecting Land, Water, and Growth (with L. Lucero), 34 Urb. Law. 971.

UN (2015). Transforming our world: the 2030 Agenda for Sustainable Development, New York.

Water Framework Directive (2001). European Commission, Brussels.

Water Management Master Plan of the Republic of Serbia, Official Gazette of the RS, No. 11/2002.

Water Management Strategy until 2034 at the territory of the Republic of Serbia. Official Gazette of the RS, No. 3/2017.

Živanović Miljković J, Popović V. 2014. Land use regulation and property rights regime over land in Serbia. Spatium 32: 22-27.

Živanović Miljković, J. 2018. Urban Land Use Regulation in Serbia: An Analysis of Its Effects on Property Rights, in: Jean-Claude Bolay, Tamara Maričić and Slavka Zeković (Eds.) A Support to Urban Development Process, EPFL and IAUS. pp. 129-147. 